\title{
Brain-derived neurotrophic factor is a novel target gene of the hsa-miR-183/96/182 cluster in retinal pigment epithelial cells following visible light exposure
}

\author{
HONGYANG LI*, YAN GONG ${ }^{*}$, HAIYAN QIAN, TINGJUN CHEN, ZIHAO LIU, \\ ZHAOCAI JIANG and SHIHUI WEI
}

Department of Opthalmology, The Chinese People's Liberation Army General Hospital, Beijing 100000, P.R. China

Received March 14, 2014; Accepted December 9, 2014

DOI: $10.3892 / \mathrm{mmr} .2015 .3736$

\begin{abstract}
Light-induced retinal injury is clinically and experimentally well-documented. It may be categorized into three types: Photothermal, photomechanical and photochemical injuries. To date, the variation in the hsa-miR-183/96/182 cluster and its potential target genes in human primary retinal pigment epithelial (RPE) cells, following visible light exposure, has not been reported. In the present study, RPE cells were exposed to $4 \mathrm{~h}$ of constant visible light. The expression of the hsa-miR-183/96/182 cluster was determined using reverse transcription-quantitative polymerase chain reaction (RT-qPCR) and its potential target genes were investigated. Additionally, hsa-miR-183, hsa-miR-96, hsa-miR-182 and has-miR-183/96/182 mimics were designed and synthesized in vitro, and transfected into the RPE cells. Subsequently, the expression of brain-derived neurotrophic factor (BDNF) mRNA and protein was measured, using RT-qPCR and western blotting, respectively. The regulation of miRNAs to the BDNF gene were then validated using a dual luciferase reporter gene assay system. The expression of hsa-miR-183, hsa-miR-96 and hsa-miR-182 significantly increased in RPE cells following $4 \mathrm{~h}$ of visible light exposure, compared with RPE cells that had been exposed to dark conditions $(\mathrm{P}<0.01)$. Following RPE cell transfection with mimics, BDNF mRNA and protein expression in the RPE cells was significantly downregulated compared with control RPE cells ( $\mathrm{P}<0.05, \mathrm{P}<0.01$, respectively). Similarly, the ratio of Renilla luciferase/firefly luciferase significantly decreased in the RPE cells of the mimic + wild type (WT) group compared with cells of the ssiCHECK $^{\mathrm{TM}}-2$ (a
\end{abstract}

Correspondence to: Professor Shihui Wei, Department of Ophthalmology, The Chinese People's Liberation Army General Hospital, 28 Fuxing Road, Beijing 100000, P.R. China

E-mail: weishihui1958@163.com

"Contributed equally

Key words: retinal pigment epithelial cells, hsa-miR-183/96/182, visible light, novel target, brain derived neurotrophic factor, light injury vector lacking the sequence of the $B D N F$ gene), wild type and mimic + mutation groups $(\mathrm{P}<0.05, \mathrm{P}<0.01)$. The present study suggests that BDNF is a target gene of the has-miR-183-96-182 cluster in RPE cells. The present study suggests an underlying protective mechanism against retinal light injury and may provide a novel target for the prevention and treatment of light-induced retinal injury.

\section{Introduction}

Retinal injury is one of most common eye diseases and is associated with old age, light damage and trauma (1-3). When eyes are directly and chronically exposed to sources of light (4-6), such as the Sun and lasers, the retina may be irreversibly damaged. Visible light (400-760 nm) may damage the retina through photochemical injury (7-9), which is considered to be the most common mechanism of light-induced retinal injury. Photochemical injury is independent of either mechanical or thermal retinal damage, and was first documented by Noell et al in 1966 (10). The authors showed that the retinas of albino rats were irreversibly damaged by continuous exposure to ambient light within the range of the visible light spectrum. Photochemical retinal-injury may be categorized into two distinct classes (11). Class I injury is characterized by exposure to low levels of white light irradiance $\left(<1 \mathrm{~mW} / \mathrm{cm}^{2}\right)$ over hours to weeks. Class II injury is characterized by exposure to high levels of white light irradiance $\left(>10 \mathrm{~mW} / \mathrm{cm}^{2}\right)$, with an action spectrum at shorter wavelengths. Rattner et al (12) found an increase in RNA transcripts coding for protective proteins, such as matrix metalloproteinase-3, serine peptidase inhibitor, clade A, member 3N; Serpin bla; and the oncostatin M receptor. Rattner et al (12) also demonstrated a decrease in the transcription of genes coding for visual cycle components in neurosensory and retinal pigment epithelial (RPE) cells in response to light, using microarray RNA blotting and in situ hybridization (12).

MicroRNA (miRNA; 22 nucleotides) is a type of small, endogenous and non-coding regulatory RNA, which is involved in the downregulation of target genes in a number of organisms, such as microorganisms and mammals (13-16). A study by Lee et al (17), demonstrated that lin-4 and let-7 in Caenorhabditis elegans caused phenotypic functional loss, and their mutation prevented them from developing 
into larval stage. Since then, numerous studies have identified miRNA in organisms, including Drosophila $(18,19)$ and mammals $(20,21)$. miRNA binds to complementary sequences in the 3'-untranslated region (UTR) of multiple target mRNAs, usually inhibiting translation or causing destabilization $(22,23)$. Certain miRNAs, such as the hsa-miR-183/96/182 cluster and hsa-miR-220, are able to silence retinal-specific genes, which are predominantly expressed in the retina (24-26). $\mathrm{Xu}$ et al (27) reported that in mouse embryonic retinas, hsa-miR-183/96/182 expression is minimal, whereas its expression increases markedly following birth and peaks in adult retinas. hsa-miR-183/96/182 expression has a function in the maturation and healthy functioning of the adult retina (27). Krol et al (28) demonstrated that hsa-miR-183/96/182 exhibits a response to light and rapid turnover as a common property of neuronal microRNAs, which is independent of the circadian cycle. Lumayag et al (29) showed that inactivation of the hsa-miR-183/96/182 cluster results in changes in retinal gene expression, postnatal functional differentiation and synaptic connectivity of photoreceptors. A study by Liu et al's (25) demonstrated that synthetic miRNA-mowers, targeting the has-miR-183/96/182 cluster, are involved in bladder cancer development. However, to the best of our knowledge, the influence of the hsa-miR-183/96/182 cluster on the downregulation of brain-derived neurotrophic factor (BDNF) in the retina has not been investigated. Therefore, the aim of the present study was to investigate the expression of hsa-miR-183/96/182 cluster following light treatment and to further investigate its regulation on the $B D N F$ gene.

\section{Materials and methods}

Culturing human primary RPE cells and experimental grouping. The human primary cultured RPE cells (Beijing Research Biotechnology Co., Ltd. Beijing, China) were resurrected and cultured in $\alpha$ modified Eagle's medium (Thermo Fisher Scientific Co., Ltd., Waltham, MA, USA) with $2 \mathrm{mM}$ L-glutamine (Beijing Beifangtongzheng Co., Ltd., Beijing, China), $100 \mathrm{U} / \mathrm{ml}$ penicillin (Beijing Beifangtongzheng Co., Ltd.), $100 \mathrm{mg} / \mathrm{ml}$ streptomycin (Beijing Beifangtongzheng Co., Ltd.) and 10\% fetal bovine serum (Thermo Fisher Scientific Co., Ltd.). Following this, the RPE cells were incubated at $37^{\circ} \mathrm{C}$ in $5 \% \mathrm{CO}_{2}$ for one week, and randomly divided into two groups when cells were planked with $80 \%$. The RPE cells in the visible light exposure group were exposed to visible light (400-760 nm) for $4 \mathrm{~h}$, while the RPE cells in the dark condition group were shaded with silver paper for $4 \mathrm{~h}$. Subsequently, cells were harvested in order to separate total RNA for reverse transcription-quantitative polymerase chain reaction (RT-qPCR). Experiments for each group were repeated at least three times.

The potential target genes of the has-miR-183/96/182 cluster were identified using TargetScan software (http://www.targetscan.org/) according to the manufacturer's instructions.

Synthesis of hsa-miR-183-96-182 mimics and transfection of the RPE cells. The hsa-miR-183, hsa-miR-96, hsa-miR-182 and has-miR-183/96/182 mimics were designed according to the sequence from the miRBase website (http://www.mirbase.org/). They were artificially synthesized by Invitrogen Life Technologies (Carlsbad, CA, USA). RPE cells were inoculated on a 12-well plate for $24 \mathrm{~h}$ prior to transfection, when planked with $80 \%$ and then transfected into RPE cells with $1 \mu \mathrm{g}$ of each vector using lipofectamine $2000^{\circledR}$ transfection reagent (Invitrogen Life Technologies), according to the manufacturer's instructions. Following $24 \mathrm{~h}$ transfection, cells were harvested to separate total RNA and total protein for subsequent experiments. Experiments for each group were repeated at least three times.

$R T$ - $q P C R$. Total RNA from the RPE cells was extracted using a miRcute miRNA isolation kit (Tiangen Biotech, Beijing, China) according to the manufacturer's instructions. The RPE cells $\left(1 \times 10^{8} / \mathrm{cm}^{3}\right)$ were harvested and disrupted by buffer MZ at room temperature (RT) for $5 \mathrm{~min}$. Chloroform $(200 \mu \mathrm{l})$ was added to the supernatant, followed by vigorous shaking for $15 \mathrm{sec}$ and incubation at RT for $5 \mathrm{~min}$. Following this, the cells were centrifuged at $12,000 \times \mathrm{g}$ at $4^{\circ} \mathrm{C}$ for $15 \mathrm{~min}$. The upper aqueous phase was transferred to a $2 \mathrm{ml}$ collection tube, and 1.5X volumes of anhydrous ethanol (Beijing Beifangtongzheng Co., Ltd.) was added followed by thorough mixing. The sample $(700 \mu \mathrm{l})$ was added into a miRelute column and centrifuged at 12,000 x g at RT for $30 \mathrm{sec}$ in order to discard the flow-through. MRD buffer (500 $\mu \mathrm{l})$ was added to the miRelute column, incubated at RT for $2 \mathrm{~min}$ and centrifuged at $12,000 \mathrm{x} \mathrm{g}$ at RT for $30 \mathrm{sec}$ to discard the flow-through. RW buffer $(700 \mu \mathrm{l})$ was added to the miRelute column, incubated at RT for $2 \mathrm{~min}$ and then centrifuged at $12,000 \mathrm{x} g$ at RT for $30 \mathrm{sec}$ in to wash the column and repeated again. The miRelute column was placed into a new collection tube and centrifuged at $12,000 \mathrm{x}$ g at $4^{\circ} \mathrm{C}$ for $1 \mathrm{~min}$ in order to dry the miRspin column. RNase-free $\mathrm{ddH}_{2} \mathrm{O}(30-100 \mu \mathrm{l}$; Beijing Beifangtongzheng Co., Ltd.) was added directly onto the miRspin column, incubated at RT for $2 \mathrm{~min}$, and centrifuged at 12,000 x $\mathrm{g}$ at RT for $2 \mathrm{~min}$ in order to elute total RNA.

In order to conduct an RT-qPCR assay of the hsa-miR-183/96/182 cluster in RPE cells, total RNA was reverse-transcribed and analyzed using a SYBR ${ }^{\circledR}$ PrimeScript $^{\mathrm{TM}}$ miRNA qPCR kit (Takara Bio, Inc., Shiga, Japan) according to the manufacturer's instructions. The following primers were used in order to amplify the hsa-miR-183, hsa-miR-96 and hsa-miR-182intheRPEcellsaftervisiblelightexposure:Forward: 5'-ACACTCCAGCTGGGTATGGCACTGGTAGAA-3' and reverse: 5'-CTCAACTGGTGTCGTGGAGTCGGCAATTCAGTTGAG AGUGAAUU-3' for hsa-miR-183, forward:5'-ACACTCCAGCTGGGTTTGGCACTAGCACATT-3' and reverse: 5'-CTCAACTGGTGTCGTGGAGTCGGCA ATTCAGTTGAGAGCAAAAA-3' for hsa-miR-9, forward: 5'-ACACTCCAGCTGGGTTTGGCAATGGTAGAACT-3' and reverse: 5'-CTCAACTGGTGTCGTGGAGTCGGCA ATTCAGTTGAGAGUGUGAG-3' for hsa-miR-182, and forward: 5'-CTCGCTTCGGCAGCACA-3' and reverse: 5'-AACGCTTCACGAATTTGCGT-3' for U6.

In order to conduct an RT-qPCR assay of BDNF in RPE cells, total RNA was reverse-transcribed using a total RNA kit II (Omega-Biotek, Norcross, GA, USA) according to the manufacturer's instructions. Amplification was conducted using SYBR ${ }^{\circledR}$ Premix Ex Taq ${ }^{\mathrm{TM}}$ II system (Takara Bio, Inc.) using the following primers: Forward: 5'-CTACGAGACCAAGTGCAATCC-3' 
and reverse: 5'-AATCGCCAGCCAATTCTCTTT-3' for BDNF.

All PCR reactions consisted of a $20 \mu \mathrm{l}$ solution of $10 \mu \mathrm{l}$ SYBR Green PCR Master Mix (Takara Bio, Inc., Shiga, Japan), $2 \mu \mathrm{l}$ forward primer, $2 \mu \mathrm{l}$ reverse primer, $1 \mu \mathrm{l}$ template and $5 \mu \mathrm{l} \mathrm{RNase-free} \mathrm{water} \mathrm{in} \mathrm{a} 0.2 \mathrm{ml}$ EP tube, and used the following PCR protocol: $95^{\circ} \mathrm{C}$ for $15 \mathrm{~min}$, followed by 45 cycles of $94^{\circ} \mathrm{C}$ for $15 \mathrm{sec}, 55^{\circ} \mathrm{C}$ for $30 \mathrm{sec}$ and $70^{\circ} \mathrm{C}$ for $30 \mathrm{sec}$. The relative quantification of miRNA was calculated using the $2^{-\Delta \Delta \mathrm{CT}}$ method.

Western blot analysis. Protein concentration was measured using the bicinchoninic acid protein assay reagent (Thermo Fisher Scientific Inc., Waltham, MA, USA) and. Samples $(\sim 35 \mu \mathrm{g})$ were separated using electrophoresis through $15 \%$ polyacrylamide gels, and transferred to polyvinylidene difluoride membranes (GE Healthcare, Cleveland, OH, USA) according to the manufacturer's instructions. The membranes were probed with mouse-derived anti-BDNF monoclonal antibody (Beijing Zhongshan Golden Bridge Biotechnology, Co., Ltd., Beijing, China) diluted to 1:1,000 in Tris-Buffered Saline with Tween-20 (TBST; Sigma-Aldrich, St. Louis, MO, USA) and mouse-derived anti- $\beta$-actin antibody diluted to 1:1,000 in TBST (Beijing Zhongshan Golden Bridge, Biotechnology, Co., Beijing China) for $1.5 \mathrm{~h}$ at RT, followed by a horseradish peroxidase-conjugated goat anti-mouse secondary antibody (1:5,000 in TBST; Beijing Zhongshan Golden Bridge Biotechnology, Co., Ltd.) and incubated at RT for $1 \mathrm{~h}$. The immunolabeled bands were examined by exposure to an X-ray film using the chemiluminescent substrate luminal reagent (GE Healthcare). The optical density of the band was scanned and quantified using the ImageJ software version 1.46 (http://www.originlab.com/).

Construction of psiCHECK $K^{T M}-2-B D N F$ (wild type) and psiCHECK-2-BDNF (mutation). The BDNF mutant was designed based on the putative miR-182 recognition site (located at 252-258 bp) in the BDNF 3'-UTR, and mutated using QuikChange Lightning Site-Directed Mutagenesis kit (Stratagene, La Jolla, CA, USA) according to the manufacturer's instructions. The BDNF cDNA encoding sequences, including wild type and mutant, were amplified using PCR of human genomic DNA, using the following primers: 5'-CTCGAGACATGTCCATGACCAGAAGGG-3' (underline indicates the Xho I restriction endonuclease site and 5'-GCGGCCGCTCACAATTAAAGCAGCATGCAA-3'

(underline indicates the Not I restriction endonuclease site. Subsequently, the PCR products and psiCHECK-2 vector were digested using restriction endonucleases Xho I (Takara Bio, Inc.) and Not I (Takara Bio, Inc.), and conjugated using $\mathrm{T}_{4}$ DNA ligase (Takara Bio, Inc.), followed by direct sequencing by Invitrogen Life Technologies.

Luciferase activity assay. In order to conduct a dual luciferase (Renilla luciferase/firefly luciferase) reporter gene assay, the 293T cells (Beijing Research Biotechnology Co., Ltd.) were cultured with Dulbecco's modified Eagle's medium, inoculated on a 12 well plate, and divided into four groups: psiCHECK-2, BDNF (wild type); mimic + BDNF (wild type); and mimic + BDNF (mutant). When the 293T cells were
Table I. miRNA mimic sequences.

\begin{tabular}{ll}
\hline Mimic name & \multicolumn{1}{c}{ Sequence $\left(5^{\prime} \rightarrow 3^{\prime}\right)$} \\
\hline miR-182 & UUUGGCAAUGGUAGAACUCACACU \\
miR-183 & UAUGGCACUGGUAGAAUUCACU \\
miR-96 & U UUGGCACUAGCACAUUUUUGCU \\
miR-183/96/182 & UUGGCAAAUGGCACUUGGCAC \\
\hline
\end{tabular}

Underline indicates seed sequences (miRNA nucleotides 2-8). miRNA, microRNA.

planked with $80 \%, 1 \mu \mathrm{g}$ of each device was then transfected into $293 \mathrm{~T}$ cells using Lipofectamine 2000 transfection reagent according to the manufacturer's instructions. Following $48 \mathrm{~h}$ transfection, the $293 \mathrm{~T}$ cells were harvested and digested with $0.25 \%$ trypsin (Takara Bio, Inc.). The 293T cells (75 $\mu \mathrm{l}$; $\left.5 \times 10^{4} / \mathrm{ml}\right)$ were separated and equal volumes of luciferase reagent was added to the cells for lysis at RT for $10 \mathrm{~min}$, following which the firefly luciferase activity was measured Subsequently, $75 \mu \mathrm{l}$ dual luciferase was added in order to fix the reagent to the plate and lysed at RT for $10 \mathrm{~min}$, and then the Renilla luciferase activity was measured. The ratio of Renilla luciferase/firefly luciferase was then calculated and a histogram was produced using Origin 9.0 software (http://www. originlab.com/).

Statistical analysis. The data were analyzed by SPSS 21.0 (IBM SPSS, Armonk, NY, USA) using Student's t-test. P<0.05 was considered to indicate a statistically significant difference.

\section{Results}

Visible light exposure increased hsa-miR-183/96/182 cluster expression in the RPE cells. hsa-miR-183, hsa-miR-96 and hsa-miR-182 transcription increased significantly in the RPE cells exposed to visible light compared with that in the RPE cells exposed to dark conditions (Fig. 1A, $\mathrm{P}<0.01$ ). The potential target genes of the hsa-miR-183/96/182 cluster in the RPE cells were predicted using TargetScan software and the results suggested that BDNF is a novel target gene of the hsa-miR-183/96/182 cluster in RPE cells (Fig. 1B).

hsa-miR-183/96/182 mimics downregulates the mRNA and protein expression of BDNF in RPE cells. In order to investigate the influence of the hsa-miR-183/96/182 cluster on BDNF mRNA and protein expression in RPE cells, mimic sequences of hsa-miR-183, hsa-miR-96, hsa-miR-182 and hsa-miR-183/96/182 were designed (Table I) The mimics were then transfected into RPE cells. BDNF mRNA expression was significantly downregulated in cells transfected with hsa-miR-183/96/182 mimics when compared with BDNF mRNA expression in the control RPE cells, including mimics of hsa-miR-183, hsa-miR-96, hsa-miR-182 (Fig. 2, P<0.01). Similarly, BDNF protein expression was significantly downregulated in the RPE cells transfected with hsa-miR-183/96/182 mimics, compared with that in the control RPE cells (Fig. 3, $\mathrm{P}<0.05$; $\mathrm{P}<0.01$ ). 
A

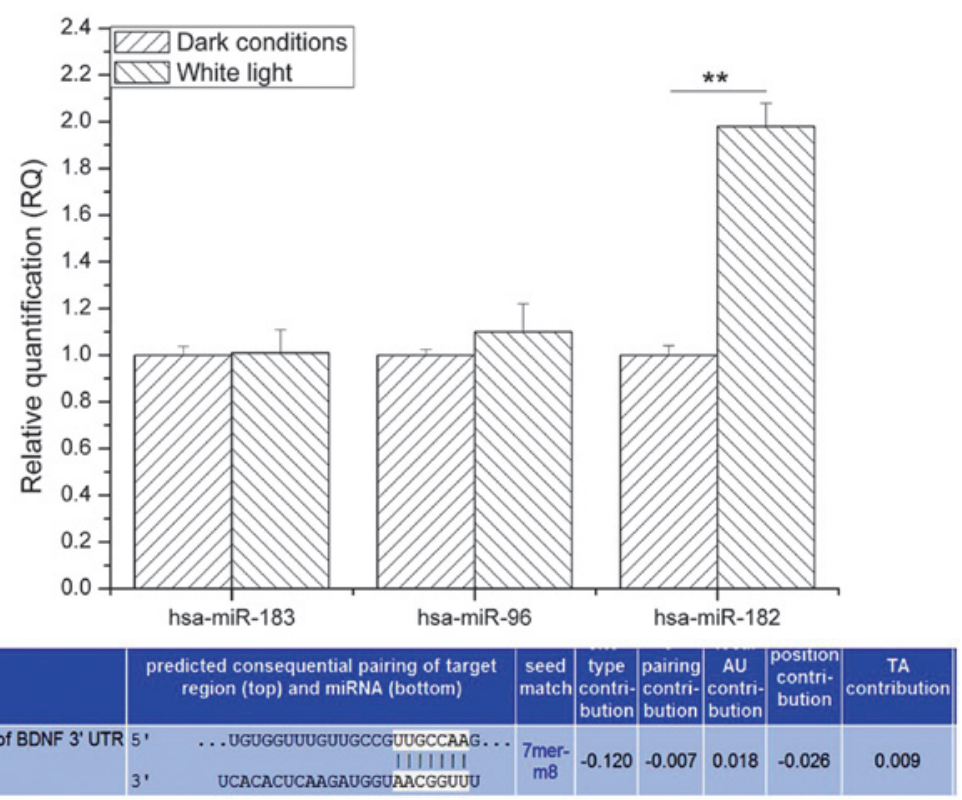

Figure 1. Expression of hsa-miR-183/96/182 cluster following light exposure, and its target genes. (A) RT-qPCR assay of hsa-miR-183, hsa-miR-96 and hsa-miR-182 transcription using RT-qPCR. The expression of hsa-miR-183, hsa-miR-96 and hsa-miR-182 increased significantly in RPE cells following exposure to visible light compared with the expression of the miRNAs in RPE cells exposed to dark conditions. ${ }^{* *} \mathrm{P}<0.01$. (B) Target gene of the hsa-miR-183/96/182 cluster. BDNF, brain-derived neurotrophic factor; miR, microRNA; RT-qPCR, reverse transcription-quantitative polymerase chain reaction; RPE, retinal pigment epithelial.

BDNF is anoveltargetgene of the hsa-miR-183/96/182 cluster.In order to validate the targeting of the hsa-miR-183/96/182 cluster to BDNF, a luciferase reporter vector was designed (Fig. 4A). Following transfection of hsa-miR-183/96/182 mimics into RPE cells, the ratio of Renilla luciferase/firefly luciferase was found to be significantly lower in mimic + wild type RPE cells, compared with the ratios in the psiCHECK-2, wild type and mimic + mutant RPE cells (Fig. 4B, $\mathrm{P}<0.01$ ). The ratio of Renilla luciferase/firefly luciferase in the RPE cells of the wild type, mimic+mutant and psiCHECK-2 RPE cells were not significantly different (Fig. 4B).

\section{Discussion}

The present study demonstrated that photostimulation upregulated the expression of hsa-miR-183,hsa-miR-96 and hsa-miR-182 in RPE cells. Artificially synthesized hsa-miR-183/96/182 cluster mimics led to the downregulation of BDNF mRNA and protein expression in RPE cells, and significantly decreased the Renilla luciferase/firefly luciferase ratio in the RPE cells of the mimic + wild type group. The results indicated that BDNF is a novel target gene of the hsa-miR-183/96/182 cluster and BDNF provides a novel target for the prevention and treatment of light-induced retinal damage.

BDNF is an important member of the nerve growth factor family $(30,31)$. It targets certain neurons of the central and peripheral nervous systems, and supports the survival of existing neurons, thereby facilitating synapse growth and differentiation (32-34). It is found in a number of tissues, including the brain $(35)$, retina $(36,37)$, central nervous system $(38,39)$ and motor neurons (40-42). In the retina, BDNF controls the development of certain amacrine cell subtypes (43-45) and regulates morphological maturation of ganglion cells (46-48).

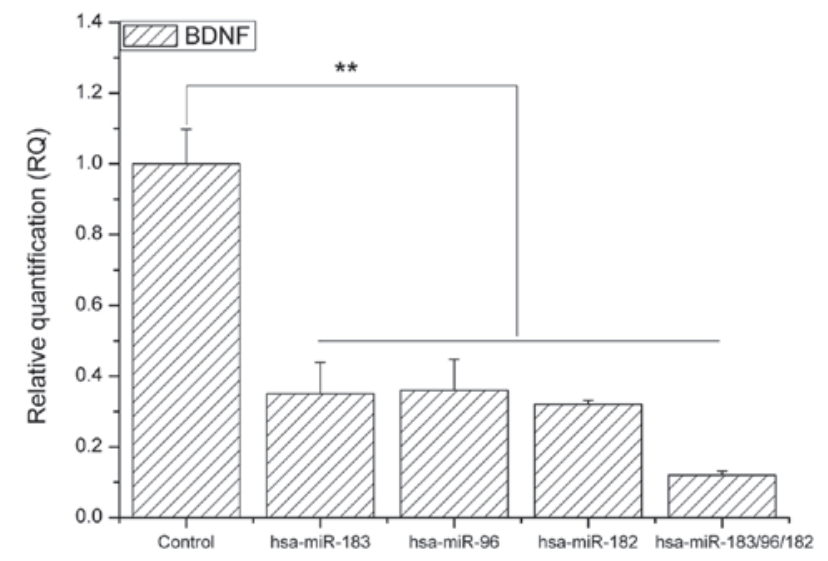

Figure 2. BDNF mRNA expression level assay conducted using reverse transcription-quantitative polymerase chain reaction in control RPE cells and RPE cells transfected with hsa-miR-183/96/182 mimics. The BDNF expression level significantly decreased in RPE cells following transfection with mimics, compared with control RPE cells. ${ }^{* *} \mathrm{P}<0.01$. BDNF, brain-derived neurotrophic factor; miR, microRNA.

Ladewig et al (49) demonstrated that BDNF activates the $\mathrm{N}$-methyl-D-aspartate receptor to develop retinal ganglion cells. Rothe et al (50) showed that BDNF exhibits specific ionic channels that are necessary for repetitive firing in early retinal ganglion cell development. Numerous studies have documented that BDNF is involved in increasing the survival of photoreceptors in RPE cells that have undergone inherited retinal degeneration, light damage and experimental retinal detachment $(51,52)$. Therefore, BDNF may be useful for the treatment and cure of light-induced retinal damage. However, to the best of our knowledge, there have been no studies investigating the regulation of BDNF by miRNAs, such as miR-183/96/182. 
A

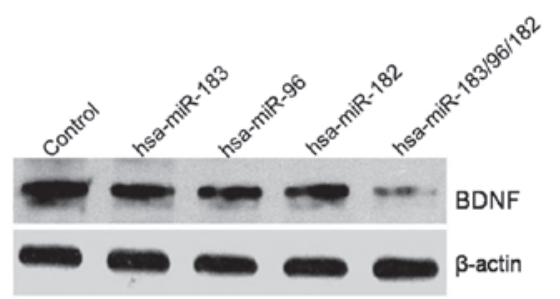

B

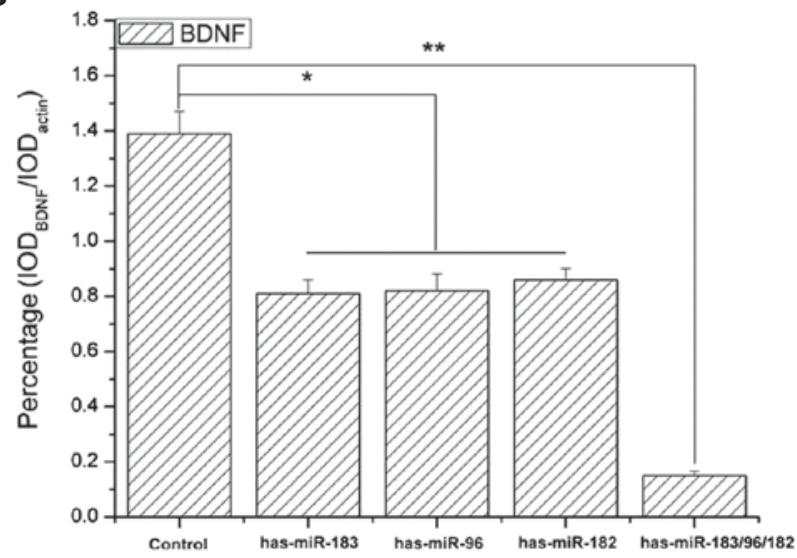

Figure 3. Evaluation of BDNF protein expression level in control RPE cells and in RPE cells transfected with hsa-miR-183/96/182 mimics, using western blotting. (A) BDNF protein expression level assay using western blotting. (B) Histogram analysis of BDNF protein expression level. Transfection with hsa-miR-183/96/182 mimics significantly decreased the expression of BDNF in RPE cells ${ }^{* * *} \mathrm{P}<0.01$. BDNF, brain-derived neurotrophic factor; RPE, retinal pigment epithelial; miRNA, microRNA; IOD, integral optical density.

A

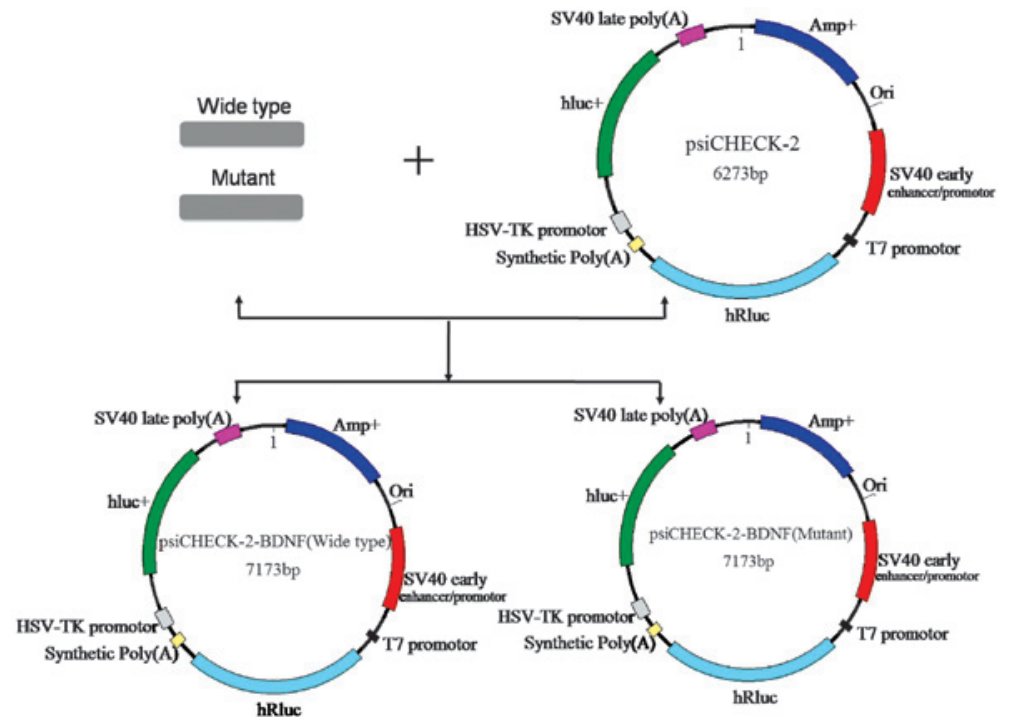

B

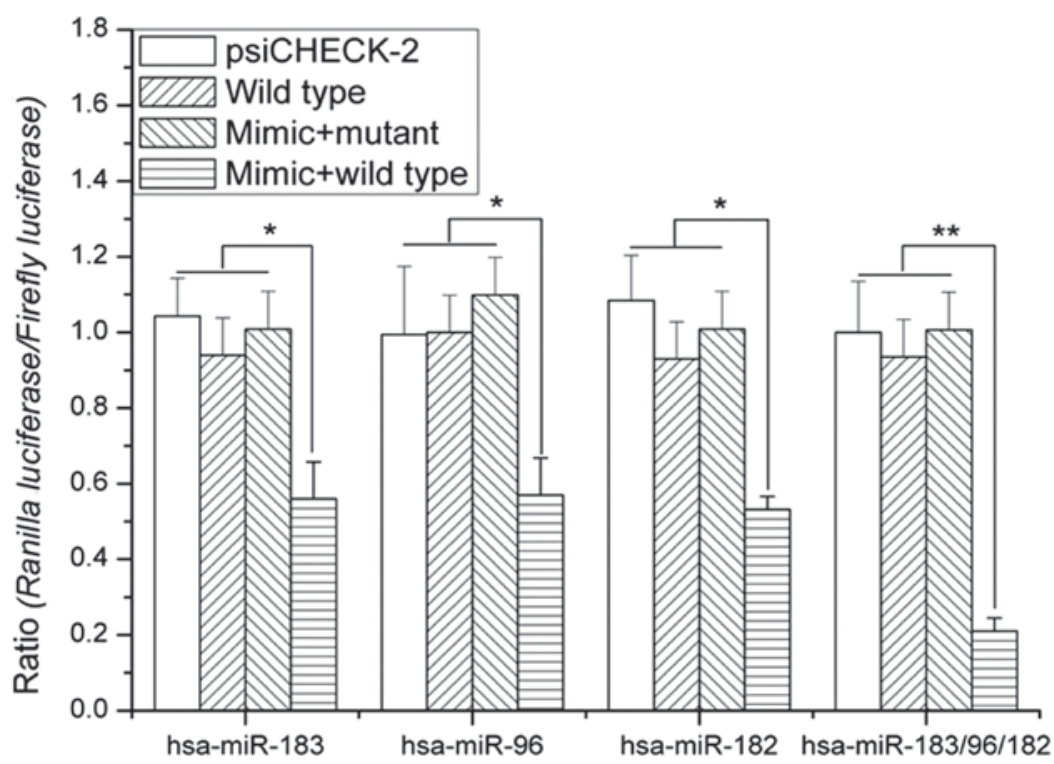

Figure 4. Luciferase activity assay. (A) Dual luciferase reporter vector construction for BDNF and its mutant variation. (B) Histogram showing the ratio of Renilla luciferase/firefly luciferase. The ratio of Renilla luciferase/firefly luciferase decreased significantly in the mimic + wild type group compared with that in the psiCHECK-2, wild type and mimic + mutant groups. " $\mathrm{P}<0.05$ and ${ }^{* *} \mathrm{P}<0.01$. BDNF, brain-derived neurotropic factor; miRNA, microRNA. 
The hsa-miR-183/96/182 cluster is a highly conserved, intergenic sensory organ-specific and paralogous miRNA cluster, and regulates an attractive candidate gene, as described previously $(26,53,54)$. The hsa-miR-183/96/182 cluster is expressed in photoreceptor cells and in the inner nuclear layer of the adult retina (24). The present study investigated the hypothesis that the miR-183/96/182 cluster is involved in BDNF gene regulation in the retina.

The expression of hsa-miR-183, hsa-miR-96 and hsa-miR-182 was measured in RPE cells following exposure to visible light or exposure to dark conditions. The results indicated that hsa-miR-183, hsa-miR-96 and hsa-miR-182 expression in the RPE cells is upregulated following exposure to visible light and downregulated following maintenance in dark conditions. Subsequently, hsa-miR-183/96/182 cluster mimics were synthesized in vitro and their regulatory effect on BDNF expression was investigated. According to a TargetScan software prediction, BDNF is a novel target of hsa-miR-183/96/182 cluster mimics. Furthermore, when RPE cells were transfected with hsa-miR-183/96/182 mimics, the expression of BDNF mRNA and protein was downregulated.

In conclusion, the results of the present study show that BDNF is a novel target of the hsa-miR-183/96/182 cluster in the retina. hsa-miR-183/96/182 mimics exhibited potential protective mechanisms against light injury in RPE cells via the BDNF gene. Therefore, the current study provides a novel approach for the prevention and treatment of light-induced retinal injury.

\section{Acknowledgements}

This study was supported by the China Postdoctoral Science Foundation (grant no. 2013M532109).

\section{References}

1. Iandiev I, Wurm A, Hollborn M, et al: Müller cell response to blue light injury of the rat retina. Invest Ophthalmol Vis Sci 49: 3559-3567, 2008.

2. Vázquez-Chona F, Song BK, Geisert EE Jr: Temporal changes in gene expression after injury in the rat retina. Invest Ophthalmol Vis Sci 45: 2737-2746, 2004 .

3. Wang AG, Chen $\mathrm{CH}$, Yang CW, et al: Change of gene expression profiles in the retina following optic nerve injury. Brain Res Mol Brain Res 101: 82-92, 2002.

4. Brod RD, Olsen KR, Ball SF and Packer AJ: The site of operating microscope light-induced injury on the human retina. Am J Ophthalmol 107: 390-397, 1989.

5. Henkes HE: Light injury to the retina. Manifestation of acute posterior multifocal placoid pigment epitheliopathy (author's transl). Klin Monbl Augenheilkd 170: 813-818, 1977 (In German)

6. Meier-Koll A: Differential diagnosis of injury to the retina by means of electrically evoked light sensations (electrophosphene) Albrecht Von Graefes Arch Klin Exp Ophthalmol 184: 177-192, 1972 (In German).

7. Wilson KM, Lynch CM, Faraci FM and Lentz SR: Effect of mechanical ventilation on carotid artery thrombosis induced by photochemical injury in mice. J Thromb Haemost 1: 2669-2674, 2003.

8. Parver LM: Photochemical injury to the foveomacula of the monkey eye following argon blue-green panretinal photocoagulation. Trans Am Ophthalmol Soc 98: 365-374, 2000.

9. Costa E, Kharlamov A, Guidotti A, Hayes R and Armstrong D: Sequelae of biochemical events following photochemical injury of rat sensory-motor cortex: mechanism of ganglioside protection. Patol Fiziol Eksp Ter 4: 17-23, 1992.

10. Noell WK, Walker VS, Kang BS and Berman S: Retinal damage by light in rats. Invest Ophthalmol 5: 450-473, 1966.
11. Cai YS, Xu D and Mo X: Clinical, pathological and photochemical studies of laser injury of the retina. Health Phys 56: 643-646, 1989.

12. Rattner A, Yu H, Williams J, Smallwood PM and Nathans J: Endothelin-2 signaling in the neural retina promotes the endothelial tip cell state and inhibits angiogenesis. Proc Natl Acad Sci USA 110: E3830-E3839, 2013.

13. Kawasaki H, Wadhwa R and Taira K: World of small RNAs: from ribozymes to siRNA and miRNA. Differentiation 72: 58-64, 2004.

14. Li CM, Zheng JG and Du GS: miRNA: a new regulator of gene expression. Yi Chuan 26: 133-136, 2004 (In Chinese).

15. Luciano DJ, Mirsky H, Vendetti NJ and Maas S: RNA editing of a miRNA precursor. RNA 10: 1174-1177, 2004

16. Huang KM, Dentchev T and Stambolian D: MiRNA expression in the eye. Mamm Genome 19: 510-516, 2008.

17. Lee RC, Feinbaum RL and Ambros V: The C. elegans heterochronic gene lin-4 encodes small RNAs with antisense complementarity to lin-14. Cell 75: 843-854, 1993.

18. Reich J, Snee MJ and Macdonald PM: miRNA-dependent translational repression in the Drosophila ovary. PLoS One 4: e4669, 2009.

19. Lee YS, Nakahara K, Pham JW, et al: Distinct roles for Drosophila Dicer-1 and Dicer-2 in the siRNA/miRNA silencing pathways. Cell 117: 69-81, 2004.

20. Liang XH, Hart CE and Crooke ST: Transfection of siRNAs can alter miRNA levels and trigger non-specific protein degradation in mammalian cells. Biochim Biophys Acta 1829: 455-468, 2013.

21. McIver SC, Roman SD, Nixon B and McLaughlin EA: miRNA and mammalian male germ cells. Hum Reprod Update 18: 44-59, 2012.

22. Zhou P, Xu W, Peng X, et al: Large-scale screens of miRNA-mRNA interactions unveiled that the 3'UTR of a gene is targeted by multiple miRNAs. PLoS One 8: e68204, 2013.

23. Fang L, Du WW, Yang X, et al: Versican 3'-untranslated region (3'-UTR) functions as a ceRNA in inducing the development of hepatocellular carcinoma by regulating miRNA activity. FASEB J 27: 907-919, 2013.

24. Zhu Q, Sun W, Okano K, et al: Sponge transgenic mouse model reveals important roles for the microRNA-183 (miR-183)/96/182 cluster in postmitotic photoreceptors of the retina. J Biol Chem 286: 31749-31760, 2011.

25. Liu Y, Han Y, Zhang H, et al: Synthetic miRNA-mowers targeting miR-183-96-182 cluster or miR-210 inhibit growth and migration and induce apoptosis in bladder cancer cells. PLoS One 7: e52280, 2012.

26. Tang H, Bian Y, Tu C, et al: The miR-183/96/182 cluster regulates oxidative apoptosis and sensitizes cells to chemotherapy in gliomas. Curr Cancer Drug Targets 13: 221-231, 2013.

27. Xu S, Witmer PD, Lumayag S, Kovacs B and Valle D: MicroRNA (miRNA) transcriptome of mouse retina and identification of a sensory organ-specific miRNA cluster. J Biol Chem 282: 25053-25066, 2007.

28. Krol J, Busskamp V, Markiewicz I, et al: Characterizing light-regulated retinal microRNAs reveals rapid turnover as a common property of neuronal microRNAs. Cell 141: 618-631, 2010.

29. Lumayag $\mathrm{S}$, Haldin $\mathrm{CE}$, Corbett $\mathrm{NJ}$, et al: Inactivation of the microRNA-183/96/182 cluster results in syndromic retinal degeneration. Proc Natl Acad Sci USA 110: E507-E516, 2013.

30. Lüesse HG, Roskoden T, Linke R, Otten U, Heese K and Schwegler H: Modulation of mRNA expression of the neurotrophins of the nerve growth factor family and their receptors in the septum and hippocampus of rats after transient postnatal thyroxine treatment. I. Expression of nerve growth factor, brain-derived neurotrophic factor, neurotrophin-3 and neurotrophin 4 mRNA. Exp Brain Res 119: 1-8, 1998.

31. Hohn A, Leibrock J, Bailey K and Barde YA: Identification and characterization of a novel member of the nerve growth factor/brain-derived neurotrophic factor family. Nature 344: 339-341, 1990.

32. Alvarez-Borda B, Haripal B and Nottebohm F: Timing of brain-derived neurotrophic factor exposure affects life expectancy of new neurons. Proc Natl Acad Sci USA 101: 3957-3961, 2004.

33. Chmielnicki E, Benraiss A, Economides AN and Goldman SA: Adenovirally expressed noggin and brain-derived neurotrophic factor cooperate to induce new medium spiny neurons from resident progenitor cells in the adult striatal ventricular zone. J Neurosci 24: 2133-2142, 2004. 
34. Pencea V, Bingaman KD, Wiegand SJ and Luskin MB: Infusion of brain-derived neurotrophic factor into the lateral ventricle of the adult rat leads to new neurons in the parenchyma of the striatum, septum, thalamus and hypothalamus. J Neurosci 21: 6706-6717, 2001

35. von Diemen L, Kapczinski F, Sordi AO, et al: Increase in brain-derived neurotrophic factor expression in early crack cocaine withdrawal. Int J Neuropsychopharmacol 17: 33-40, 2014.

36. Abu El-Asrar AM, Nawaz MI, Siddiquei MM, Al-Kharashi AS, Kangave D and Mohammad G: High-mobility group box-1 induces decreased brain-derived neurotrophic factor-mediated neuroprotection in the diabetic retina. Mediators Inflamm 2013 863036, 2013.

37. Chen R, Yin XB, Peng CX and Li GL: Effect of brain-derived neurotrophic factor on $\mathrm{c}$-jun expression in the rd mouse retina. Int J Ophthalmol 5: 266-271, 2012.

38. Numakawa T, Adachi N, Richards M, Chiba S and Kunugi H: Brain-derived neurotrophic factor and glucocorticoids: reciprocal influence on the central nervous system. Neuroscience 239 157-172, 2013.

39. Yan Q, Rosenfeld RD, Matheson CR, et al: Expression of brain-derived neurotrophic factor protein in the adult rat central nervous system. Neuroscience 78: 431-448, 1997.

40. Niu C and Yip HK: Neuroprotective signaling mechanisms of telomerase are regulated by brain-derived neurotrophic factor in rat spinal cord motor neurons. J Neuropathol Exp Neurol 70 : 634-652, 2011

41. Fryer HJ, Wolf DH, Knox RJ, et al: Brain-derived neurotrophic factor induces excitotoxic sensitivity in cultured embryonic rat spinal motor neurons through activation of the phosphatidylinositol 3-kinase pathway. J Neurochem 74: 582-595, 2000.

42. Wang W, Salvaterra PM, Loera S and Chiu AY: Brain-derived neurotrophic factor spares choline acetyltransferase mRNA following axotomy of motor neurons in vivo. J Neurosci Res 47 134-143, 1997.

43. Fujieda H and Sasaki H: Expression of brain-derived neurotrophic factor in cholinergic and dopaminergic amacrine cells in the rat retina and the effects of constant light rearing. Exp Eye Res 86: 335-343, 2008.
44. Cellerino A, Arango-González BA and Kohler K: Effects of brain-derived neurotrophic factor on the development of NADPH-diaphorase/nitric oxide synthase-positive amacrine cells in the rodent retina. Eur J Neurosci 11: 2824-2834, 1999.

45. Cellerino A and Kohler K: Brain-derived neurotrophic factor/neurotrophin-4 receptor TrkB is localized on ganglion cells and dopaminergic amacrine cells in the vertebrate retina. J Comp Neurol 386: 149-160, 1997.

46. Leake PA, Hradek GT, Hetherington AM and Stakhovskaya O: Brain-derived neurotrophic factor promotes cochlear spiral ganglion cell survival and function in deafened, developing cats. J Comp Neurol 519: 1526-1545, 2011.

47. Bonnet D, Garcia M, Vecino E, Lorentz JG, Sahel J and Hicks D: Brain-derived neurotrophic factor signalling in adult pig retinal ganglion cell neurite regeneration in vitro. Brain Res 1007: 142-151, 2004.

48. Nakazawa T, Tamai M and Mori N: Brain-derived neurotrophic factor prevents axotomized retinal ganglion cell death through MAPK and PI3K signaling pathways. Invest Ophthalmol Vis Sci 43: 3319-3326, 2002.

49. Ladewig T, Fellner S, Zrenner E, Kohler K and Guenther E: BDNF regulates NMDA receptor activity in developing retinal ganglion cells. Neuroreport 15: 2495-2499, 2004.

50. Rothe T, Bähring R, Carroll P and Grantyn R: Repetitive firing deficits and reduced sodium current density in retinal ganglion cells developing in the absence of BDNF. J Neurobiol 40: 407-419, 1999.

51. Zhang M, Mo X, Fang Y, et al: Rescue of photoreceptors by BDNF gene transfer using in vivo electroporation in the RCS rat of retinitis pigmentosa. Curr Eye Res 34: 791-799, 2009.

52. Caffé AR, Söderpalm AK, Holmqvist I and van Veen T: A combination of CNTF and BDNF rescues rd photoreceptors but changes rod differentiation in the presence of RPE in retinal explants. Invest Ophthalmol Vis Sci 42: 275-282, 2001.

53. Weeraratne SD, Amani V, Teider N, et al: Pleiotropic effects of miR-183 96 182 converge to regulate cell survival, proliferation and migration in medulloblastoma. Acta Neuropathol 123: 539-552, 2012.

54. Mihelich BL, Khramtsova EA, Arva N, et al: miR-183-96-182 cluster is overexpressed in prostate tissue and regulates zinc homeostasis in prostate cells. J Biol Chem 286: 44503-44511, 2011. 